\title{
APLIKASI TERAPI KOGNITIF SEBAGAI UPAYA PENCEGAHAN TERJADINYA KEGAWATDARURATAN KARDIOVASKULER PADA PASIEN HIPERTENSI DI MASA PANDEMI COVID-19 DI DESA KOTAWAY OKU SELATAN
}

https://doi.org/10.33024/jkpm.v4i6.4545

\author{
Trilia $^{1}$, Lilis Susanti ${ }^{2 *}$, Merry Diana ${ }^{3}$ \\ IKesT Muhammadiyah Palembang
}

Disubmit: 15 Juni 2021 Diterima: 30 Juni 2021 Diterbitkan: 01 Desember 2021

Email Korespondensi: lilissusanti.272@gmail.com

\begin{abstract}
ABSTRAK
Hipertensi merupakan salah satu penyakit yang tergolong silent killer atau penyakit yang dapat membunuh manusia secara tidak terduga. Pengetahuan tentang hipertensi dan bagaimana penatalaksanaanya serta cara pencegahan terjadinya komplikasi sangat diperlukan pasien hipertensi dalam mengontrol tekanan darahnya dengan baik. Kesadaran diri pasien hipertensi untuk melakukan perawatan diri dengan tepat dan teratur sangat penting untuk mencegah komplikasi pada penderita hipertensi. Tujuan pengabdian masyarakat ini untuk mengetahui pentingnya aplikasi terapi kognitif tentang perawatan hipertensi dalam pencegahan kejadian stroke di Desa Kotaway Kabupaten Ogan Komering Ulu Selatan. Solusi yang ditawarkan dengan memberikan Terapi Kognitif berupa pengetahuan tentang perawatan hipertensi melalui ceramah dan pendidikan kesehatan. Kegiatan ini dilaksanakan pada tanggal 22 Februari -12 Maret 2021 di Desa Kotaway OKU Selatan bersamaan dengan kegiatan posyandu lansia. Peserta dalam kegiatan 14 pasien hipertensi. Untuk mengukur keberhasilan terapi kognitif ini dilakukan pre dan post tes selama kegiatan berlangsung. Setelah dilakukan terapi kognitif pada pasien hipertensi, terjadi peningkatan pengetahuan sehingga mencegah terjadinya komplikasi pada pasien hipertensi
\end{abstract}

Kata Kunci: Terapi kognitif, pencegahan dan hipertensi

\begin{abstract}
Hypertension is a disease that is classified as a silent killer or a disease that can kill humans unexpectedly. Knowledge of hypertension, how to manage it, and how to prevent complications are needed by hypertensive patients to control their blood pressure properly. Self-awareness of hypertensive patients to carry out self-care appropriately and regularly is very important to prevent complications in people with hypertension. The purpose of this community service is to find out the importance of the application of cognitive therapy on hypertension care in preventing stroke in Kotaway Village, South Ogan Komering Ulu District. The solution offered is by providing Cognitive Therapy in the form of knowledge about hypertension care through lectures and health education. This activity was carried out February 22 - March 12, 2021 in Kotaway Village, South OKU in conjunction with elderly Integrated Healthcare Center (Posyandu)
\end{abstract}


activities. Participants in the activity were 14 hypertensive patients. To measure the success of this cognitive therapy, pre and post tests were carried out during the activity. After doing the cognitive therapy in hypertensive patients, there is increasing in knowledge so as to prevent complications in hypertensive patients.

Keywords: Cognitive therapy, prevention and hypertension

\section{PENDAHULUAN}

Hipertensi merupakan salah satu penyakit yang tergolong silent killer atau penyakit yang dapat membunuh manusia secara tidak terduga. Penyakit ini dijuluki silent killer karena penderita sering tidak menyadari apabila tekanan darah yang dimilikinya tidak normal atau melebihi ambang batas. Pasien hipertensi seharusnya mengerti dan menumbuhkan kesadaran diri akan penyakitnya dan dapat melakukan perawatan secara mandiri untuk mencegah kejadian komplikasi salah satunya stroke yang dapat menyebabkan kematian. Realitanya banyak penderita hipertensi yang belum melakukan upaya pencegahan dalam perilaku perawatan pengontrolan diri untuk menghindari terjadinya komplikasi (Nisa, 2019)

Hipertensi termasuk penyakit dengan angka kejadian (prevalensi) yang cukup tinggi. Data WHO (World Health Orgnization) tahun 2015 menunjukkan sekitar 1,13 miliar orang di dunia menderita hipertensi (Depkes RI, 2013). Di Indonesia berdasarkan Riset Kesehatan Dasar (Riskesdas) 2013, Survei Indikator Kesehatan Nasional (Sirkenas) tahun 2016 menunjukkan peningkatan prevalensi hipertensi pada penduduk usia 18 tahun ke atas sebesar 32,4\% (Depkes, 2018). Sedangkan dari data Dinas Kesehatan kota Palembang, angka kejadian penyakit hipertensi mengalami peningkatan dari tahun ketahun. Pada tahun 2014 yaitu sebanyak 6740 orang, pada tahun 2015 sebanyak 7944 orang, pada tahun 2016 sebanyak 8686 orang dan bulan januari sampai september tahun 2017 sebanyak 6973 (Profil Dinkes Kota Palembang 2017 dalam Rosita dan Khoirin 2018), prevalensi hipertensi sebesar $34,4 \%$ pada penduduk usia $>15$ tahun, maka estimasi penderita hipertensi di Kabupaten Ogan Komering Ulu tahun 2019 sebesar 90.423 orang. Jumlah penderita hipertensi yang mendapat pelayanan sesuai standar sebanyak 13.901 orang $(15,4 \%)$, terjadi peningkatan cakupan pelayanan hipertensi jika dibandingkan dengan tahun 2018 sebesar 10,9\% (sebesar 4,5\%)(Dinkes OKU, 2020), sedangkan hasil observasi yang dilakukan penulis pada tanggal 4 Pebruari 2021 yang lalu di UPTD Buay Pemaca Desa Kotaway OKU Selatan didapatkan data kunjungan 1 bulan terakhir pasien hipertensi sebanyak 26 pasien, sebelum pandemi covid-19 berkisar 50 - 75 kunjungan perbulan komplikasi salah satunya stroke yang dapat menyebabkan kematian (Manuntung, 2019).

Kesadaran diri pasien hipertensi untuk melakukan perawatan diri dengan tepat dan teratur sangat penting untuk mencegah komplikasi pada penderita hipertensi. Banyak ditemukan pasien hipertensi yang tidak mampu mengelola hipertensinya dengan tepat sehingga berkembang menjadi hipertensi dengan komplikasi. Untuk menghindari terjadinya komplikasi hipertensi yang fatal, maka perlu mengambil tindakan pencegahan yang tepat (stop high blood pressure) seperti, dengan perubahan gaya hidup yaitu tidak merokok, lakukan olah raga secara teratur, kurangi berat badan jika overweigh, diet hipertensi yaitu kurangi sodium, alokohol dan kafein, 
makan dengan diet sehat termasuk didalamnya perbanyak makan buah dan kurangi lemak, serta mengendalikan stress dengan baik. Masih banyak pasien hipertensi yang tidak terkontrol dan mengalami hambatan dalam melakukan perawatan diri karena faktor kurangnya pengetahuan, dan tidak adanya keyakinan dari pasien itu sendiri (Nisa, 2019).

Dimasa pandemic covid-19 berbagai upaya dilakukan pemerintah untuk mencegah terjadinya penyebaran virus, salah satunya dengan mengurangi interaksi manusia dengan manusia lain (sosial distanching), menjaga jarak ini juga dilakukan pasien hipertensi, mereka sengaja membatasi diri mengurangi kunjungan ke rumah sakit atau puskesmas dalam rangka menghindari penularan covid-19. Hal ini sesuai dengan peraturan pemerintah tentang protocol kesehatan, Virus covid-19 menular melalui droplet dan kontak dengan benda yang terkontaminasi. Usaha yang direkomendasikan dalam mencegah penyebaran infeksi ini ialah dengan menerapkan etika batuk dan bersin, cuci tangan menggunakan sabun secara teratur, memasak daging dan telur hingga matang, serta menghindari kontak dekat dengan orang yang memiliki gejala penyakit pernapasan seperti batuk dan bersin (Kemenkes RI, 2020).

Sehingga pasien hipertensi cenderung mengurangi kunjungan ke pelayanan Kesehatan dengan alasan khawatir tertular virus covid-19. Dari penjelasan diatas diperlukan solusi untuk mengurangi dampak terjadinya komplikasi utama seperti stroke pada pasien hipertensi. Pemberian pendidikan kesehatan tentang cara melakukan pencegahan terjadinya komplikasi merupakan solusi untuk mengatasi berkurangnya kejadian stroke pada pasien hipertensi. Berdasarkan uraian diatas, maka penulis tertarik untuk melakukan mengabdian masyarakat tentang "Aplikasi Terapi Kognitif sebagai Upaya Pencegahan kegawardaruratan Kardiovaskuler pada pasien hipertensi di Desa Kotaway OKU Selatan.

\section{MASALAH}

Prevalensi hipertensi di Kabupaten Ogan Komering Ulu sebesar 34,4\% pada penduduk usia $>15$ tahun, maka estimasi penderita hipertensi ditahun 2019 sebesar 90.423 orang. Jumlah penderita hipertensi yang mendapat pelayanan sesuai standar sebanyak 13.901 orang $(15,4 \%)$, terjadi peningkatan cakupan pelayanan hipertensi jika dibandingkan dengan tahun 2018 sebesar 10,9\% (sebesar 4,5\%) (Dinkes OKU, 2020), sedangkan data kunjungan pasien hipertensi 1 bulan terakhir di UPTD Buay Pemaca Desa Kotaway sebanyak 26 pasien, dalam kondisi normal sebelum mewabahnya pandemic covid-19, jumlah kunjungan pasien dengan hipertensi sampai 75 pasien.

Penting bagi Pasien hipertensi melakukan kontrol rutin dan mendapatkan pelayanan Kesehatan baik di rumah sakit maupun di puskesmas, sejak merebaknya pandemi covid-19, pasien mengurangi aktivitas diluar rumah guna menghindari kontak langsung dengan orang lain, sehingga kebanyakan pasien hipertensi melakukan perawatan sendiri di rumah tanpa mengawasan petugas kesehatan. Situasi pandemic covid-19 juga berkontribusi besar terhadap berkurangnya kesadaran penderita hipertensi untuk melakukan tindakan pencegahan akibat kurangnya pengetahuan. Kehadiran petugas kesehatan sangat diperlukan dalam menyelesaikan masalah kesehatan, untuk itu diperlukan pendidikan kesehatan sebagai upaya pencegahan terjadinya komplikasi pada pasien hipertensi. 


\section{Diteruskan}

Kota Way - Buay Pemaca, Kabupaten

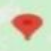

Ogan Komering Ulu Selatan,

Sumatera Selatan.

maps.app.goo.gl

Kota Way

Buay Pemaca, Kabupaten Ogan

Komering Ulu Selatan, Sumatera Selatan

https://maps.app.goo.gl

/kWqY3n3p6FEYNM7k7

Gambar 2.1 peta Lokasi Kegiatan pengabdiam kepada masyaraka

\section{METODE}

a. Tujuan Persiapan

1) Berkoordinasi dengan bagian LP2MI dalam pengurusan surat izin pengabdian masyarakat.

2) Menyiapkan materi dan bahan edukasi berupa penyuluhan untuk pemberian informasi.

3) mengenai penyakit hipertensi meliputi pengertian, penyebab, tanda dan gejala, Factor resiko dan cara pencegahan komplikasi pasien hipertensi dimasa pandemic Covid-19.

4) Menyiapkan pertanyaan/ pernyataan untuk pre test dan post test.

5) Menyiapkan berita acara kegiatan dan daftar hadir kegiatan.

\section{b. Tahapan Pelaksanaan .}

1) Memberikan informasi tentang pelaksanaan kegiatan pengabdian masyarakat kepada peserta kegiatan.

2) Persamaan persepsi tentang pencegahan hipertensi selama masa pandemic COVID-19.

3) Melakukan kegiatan pre test.

4) Memberikan Pendidikan Factor tentang penyakit hipertensi dan pencegahannya melalui materi yang telah disiapkan. Menjelaskan secara detail komplikasi dari hipertensi seperti penyakit jantung dan stroke yang merupakan salah satu kegawatdarutan kardiovaskuler .

5) Memberikan kesempatan untuk berdiskusi kepada peserta kegiata.

6) Melakukan kegiatan post test.

7) Menganalisis hasil kegiatan

\section{HASIL DAN PEMBAHASAN}

Pengabdian masyarakat ini dilaksanakan dari tanggal 22 Februari - 12 Maret 2021, di rumah warga lansia Desa Kotaway kabupaten OKU Selatan. Mitra dalam kegiatan ini adalah kader posyandu lansia di Desa Kotaway kabupaten OKU Selatan. Peserta pengabdian yaitu 14 orang lansia penderita hipertensi. Metode yang digunakan dalam pengabdian masyarakat ini adalah pengisian kuesioner pengetahuan peserta tentang penyakit hipertensi dan pencegahan komplikasi stroke. Kemudian melakukan pemeriksaan tekanan darah yang dibantu oleh mahasiswa program studi DIII keperawatan. Penyuluhan dan ceramah dilakukan melalui penyampaian materi terkait pengertian, faktor penyebab, tanda gejala dan pencegahan komplikasi hipertensi. Kegiatan dilakukan secara individu dengan cara mendatangi 
rumah lansia satu persatu didampingi kader posyandu lansia, penyuluhan dilakukan secara individu mengingat saat ini sedang masa 1477actor1477c covid-19 guna menghindari terjadinya penularan, dan kerumunan, Kegiatan yang terakhir adalah diskusi dan tanya jawab tentang penyakit hipertensi dilakukan setelah penyuluhan, kemudian dilakukan pengisian kuesioner pengetahuan tentang penyakit hipertensi dan pencegahan komplikasi stroke.

Kegiatan pengabdian masyarakat ini guna mencegah komplikasi hipertensi dilaksanakan di rumah warga . Pelaksanaan kegiatan terapi kognitif melalui penyuluhan pencegahan komplikasi hipertensi pada lansia terlaksana tanpa hambatan dan lancar. Pelaksanaan kegiatan ini dibagi menjadi tiga tahapan sebagai berikut:

a. Pemeriksaan tekanan darah

Tahapan yang pertama adalah pemeriksaan tekanan darah yang dibantu oleh mahasiswa Program Studi DIII Keperawatan Fakultas IImu Kesehatan dan Tehnologi Muhammadiyah Palembang.
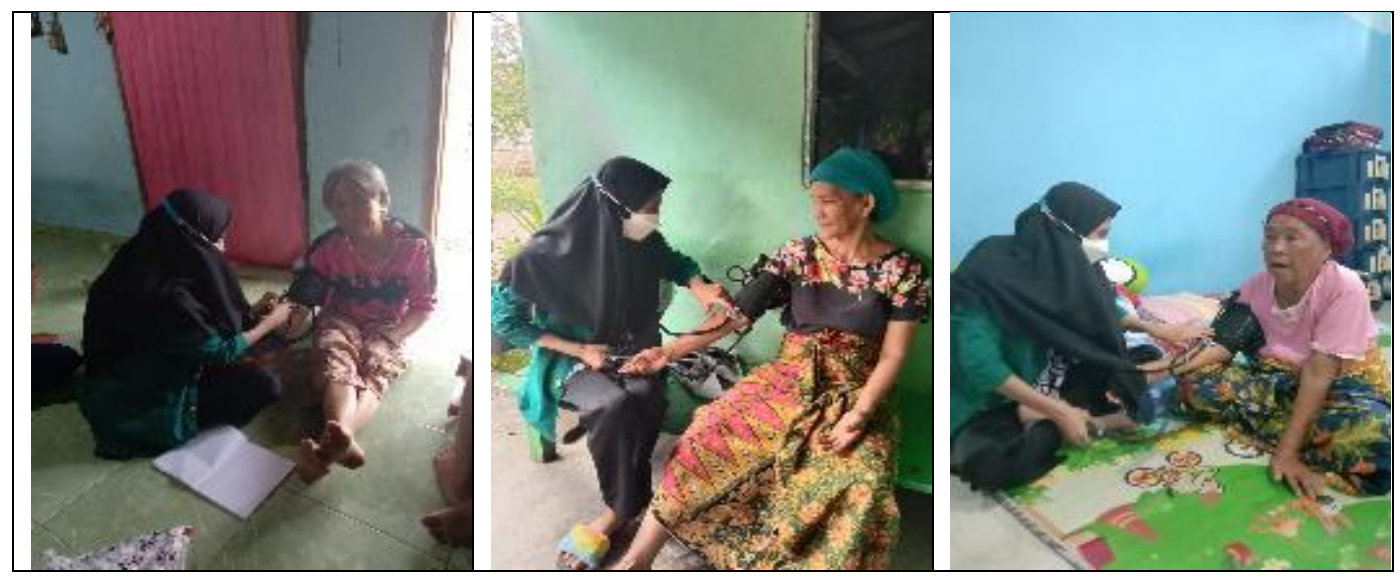

Gambar 1. Kegiatan pemeriksaan tekanan darah

b. Proses terapi koqnitif dengan metode ceramah

Tahapan kedua adalah menjelaskan materi dengan melaksanakan metode ceramah. Pada tahapan ini lansia diberikan penjelasan materi tentang hipertensi meliputi: pengertian, faktor penyebab, tanda gejala, komplikasi dan cara pencegahannya.
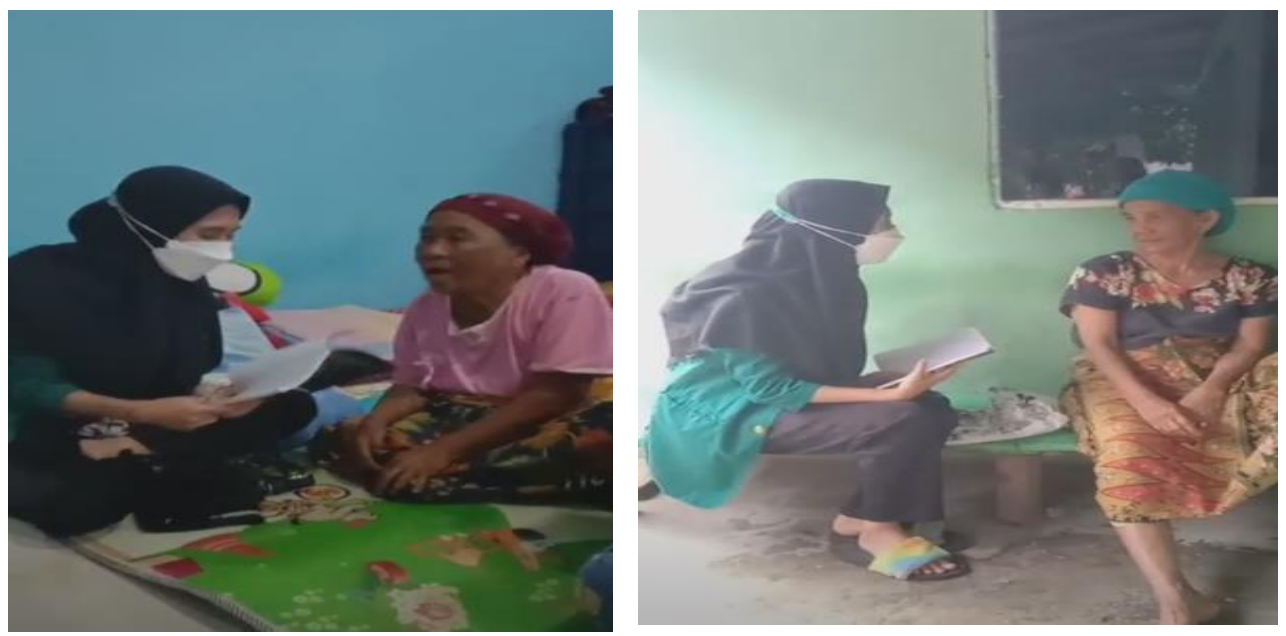

Gambar 2. Kegiatan penyampaian materi. 
3) Kegiatan diskusi tanya jawab tentang materi yang telah disampaikan

Tahapan yang ketiga yaitu pelaksanaan kegiatan diskusi (Gambar 3). Pada tahapan ini menerapkan metode diskusi ( tanya jawab). Lansia berdiskusi tentang materi pengertian, penyebab, faktor resiko dan pencegahan komplikasi hipertensi yang telah dijelaskan. Bagi lansia yang kurang paham maka lansia diperkenankan untuk bertanya. Selanjutnya diakhir kegiatan lansia diberikan beberapa evaluasi terkait materi yang sudah dibahas.
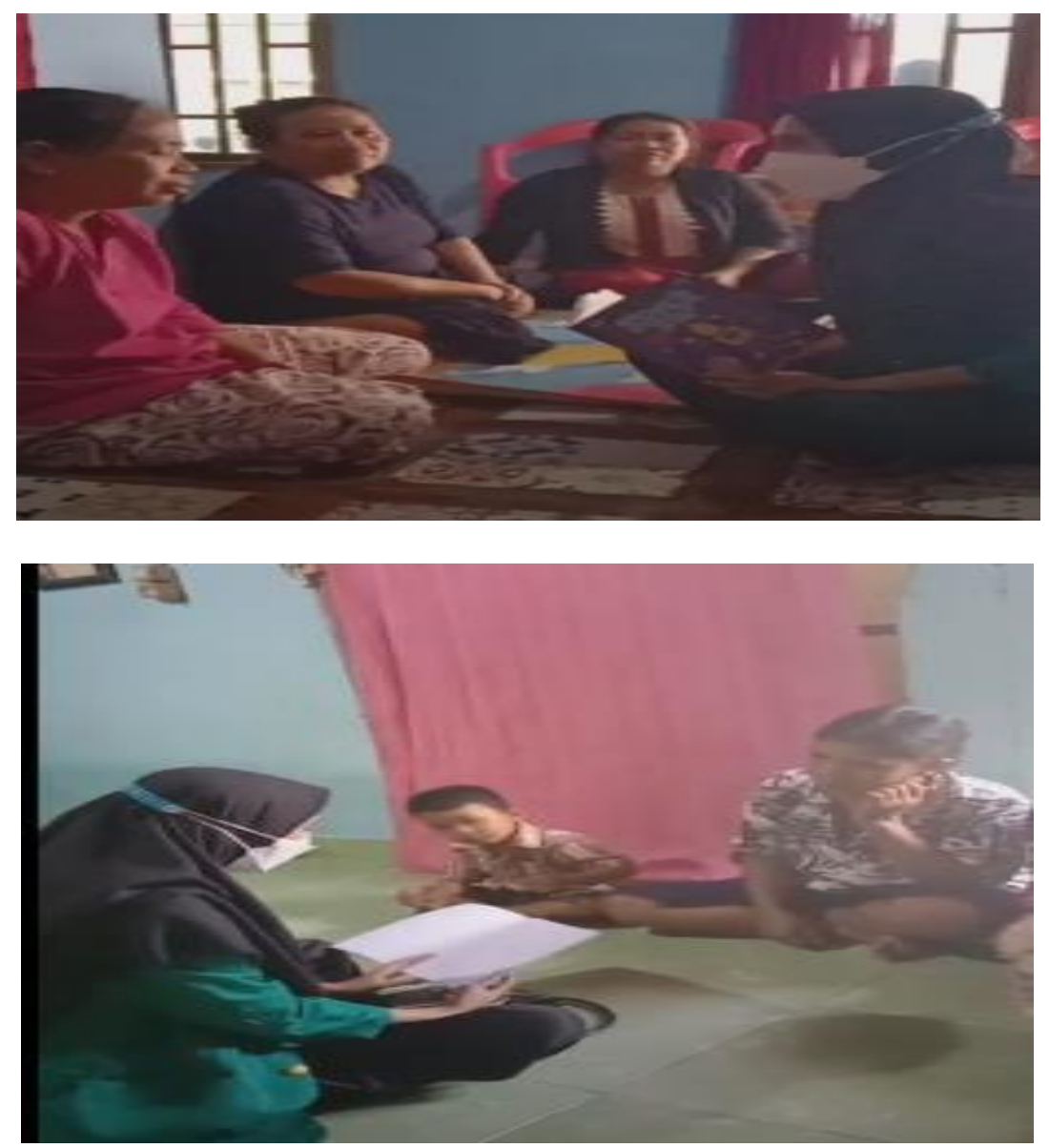

Gambar 3. Kegiatan Diskusi

Keberhasilan terapi koqnitif tentang pencegahan komplikasi hipertensi di rumah warga lansia bertujuan meningkatkan motivasi lansia dapat dilihat dari antusiasme dan semangat lansia yang ikut dalam kegiatan selalu bertanya terkait penyakit hipertensi. Selain itu lansia juga berperan aktif dalam melaksanakan proses berdiskusi, mereka tanpa merasa segan dalam mengajukan pertanyaan jika terdapat materi yang tidak jelas dan sulit dimengerti. Mereka juga aktif menjawab pertanyaan seputar materi yang telah disampaikan oleh fasilitator. Kegiatan terapi koqnitif tentang pencegahan komplikasi hipertensi ini membantu lansia dalam mengatasi ketiadaktahuannya tentang pencegahan komplikasi hipertensi. Sebagian besar lansia sudah bersikap positif terhadap pencegahan komplikasi hipertensi. (Fitria, 2013) 


\section{KESIMPULAN}

Kesimpulan dalam kegiatan terapi koqnitif pencegahan komplikasi hipertensi di rumah warga lansia Desa Kotaway Kabupaten OKU Selatan dapat meningkatkan pengetahuan lansia tentang hipertensi dan pencegahan komplikasinya, menumbuhkan motivasi lansia untuk mencegah komplikasi penyakit dan melaksanakan gaya hidup yang baik dalam kehidupan sehai-hari. Keberhasilan terapi koqnitif lansia untuk menumbuhkan motivasi dalam pencegahan komplikasi penyakit hipertensi adalah dengan antusias dan semangat dalam mengikuti kegiatan. Selain itu lansia juga aktif dalam melakukan tanya jawab dengan materi yang disampaikan dan berdiskusi tentang pencegahan komplikasi hipertensi. Pelaksanaan kegiatan pengabdian ini terlaksana sesuai harapan yaitu kelancaran proses edukasi dan diskusi tanpa adanya hambatan yang cukup berarti. Sesuai dengan hal itu, perlu adanya terapi koqnitif lansia secara berkesinambungan yang dapat dilakukan pada saat jadwal posyandu sebagai upaya membantu lansia dalam meningkatkan kualitas hidup mereka agar dapat mencegah komplikasi penyakit hipertensi sehingga masalah kegawatdaruratan kardiovaskuler tidak terjadi pada lansia.

\section{DAFTAR PUSTAKA}

Depkes RI. (2013). Laporan Hasil Riset Kesehatan Dasar Indonesia tahun 2013. Depkes RI. (2018). Survey Indikator Kesehatan Nasional tahun 2016.

Dinkes OKU. (2020). Profil Kesehatan Kabupaten Ogan Komering Ulu tahun 2020.

Fernalia, F., Busjra, B., \& Jumaiyah, W. (2019). Efektivitas Metode Edukasi Audiovisual terhadap Self Management pada Pasien Hipertensi. Jurnal Keperawatan Silampari, 3(I), 221-233. https: //doi.org/https://doi.org/10.31539/jks.v3i1.770

Fitria. (2013). penyuluhan hipertensi pada pasien puskesmas kebon jahe kota bandar lampung. Journal of Chemical Information and Modeling, 53(9), 1689-1699.

Joeliantina, A., \& Nisa, A. K. (2019). Kesadaran Diri Pasien Hipertensi dalam Pencegahan Kejadian Stroke Di Puskesmas Tambakrejo Surabaya. Prosiding ..., 263-266. http://semnas.poltekkesdepkessby.ac.id/index.php/2019/article/view/92

Kementrian Kesehatan RI. (2020). Pedoman Pencegahan dan Pengendalian Coronavirus Disease (COVID-19).

Maruntung. (2019). Terapi Perilaku Kognitif Pada Pasien Hipertensi. Wineka Media.

Nuraini Bianti,(2015). RISK FACTORS OF HYPERTENSION Bianti. https://juke.kedokteran.unila.ac.id/index.php/majority/article/viewF ile/602/606

Rosita, M., \& Kunci, K. (2018). Faktor-Faktor Yang Berhubungan Dengan Kepatuhan Diet Pada Pasien Hipertensi Di Puskesmas Pakjo Palembang Tahun 2018 Pendahuluan Data WHO (World Health tahun 2025 atau sekitar $29 \%$ dari total penduduk dunia , dimana penderitanya lebih banyak wanita ( $30 \%$. 1-15.

Suprayitno, E., \& Huzaimah, N. (2020). Pendampingan Lansia Dalam Pencegahan Komplikasi Hipertensi. SELAPARANG Jurnal Pengabdian Masyarakat Berkemajuan, 4(1), 518. https://doi.org/10.31764/jpmb.v4i1.3001 